\title{
RUSSELL ON TECHNOLOGY AND COMMON SENSE
}

\author{
STEPHEN LEACH
}

\begin{abstract}
This article examines the distinction that Russell drew between his work as a philosopher and his work as a journalist. It explains why, when warning against the threat posed by a nuclear arms race, Russell thought it better to write as a journalist (speaking on behalf of common sense) rather than as a philosopher. It is argued that to put aside philosophy in favour of common sense is, in this instance, a mistake.

Key words: Bertrand Russell; technology; common sense; nuclear weapons; philosophy.
\end{abstract}

He possessed a great deal of philosophical insight, or common sense that looked like it.

Georg Christoph Lichtenberg (1768-1771, p. 44)

Unless technology improves we are doomed. ${ }^{1}$

With that I have no wish to argue, but can a similar claim be made for philosophy? I would argue that in view of the potentially self-destructive power of the technology that has already been developed, and that we are continuing to develop-because, in short, technology can also kill us-an appreciation and understanding of philosophy is also essential to our survival.

The claim is contentious, for philosophy is currently seen as of less practical use than natural science, on which technology depends (and vice versa). For now, Wittgenstein's view that philosophy "leaves everything as it is" (Wittgenstein, 1953, I §124) holds the field. ${ }^{2}$ But it must not be allowed to.

At first glance, it might seem that Russell realised this. From the 1920s onwards he warned that we must give more thought to the ends to which technology is developed. (e.g. Russell, 1924, 1931). These ends might be good or bad but they are not made good simply because they involve the development of technology. Already in 1923 Russell had warned

\footnotetext{
1 "If we don't improve our technology, the question isn't whether humanity will go extinct, but merely how: will an asteroid, a super-volcano, the burning heat of the aging Sun or some other calamity get us first?" (Tegmark, 2017, p. 248).

2 See also (Wittgenstein, 1953, p. 226). "What has to be accepted, the given, is - so one could say forms of life." Winner notes the conservative nature of this maxim in relation to rapidly developing technologies (Winner, 1986, pp. 11-13).
} 
that work on the structure of the atom might well "ultimately be used for making more deadly explosives and projectiles than any yet invented" (Russell, 1923, p. 11). After the Second World War such warnings came to seem prophetic.

However, in issuing these warnings, Russell, by his own lights, was working as a journalist rather than a philosopher; and, though it might be argued that his journalism was itself primarily in the area of applied ethics (i.e. part of philosophy), Russell himself disavowed any connection between his philosophy and his journalism. He did not believe his journalism "rose to the dignity of philosophy" (Pigden, 1999, xi). Thus, strangely, in writing about the proliferation of nuclear weapons-one of the most urgent problems of his, and our, time-one of the most renowned philosophers of the twentieth century shunned the label of 'philosopher.'

By way of background, it should be noted that Russell was, already since 1913, a moral relativist. As such, he had come to believe, albeit reluctantly, that-although he had plenty to say, as a journalist, from a moral point of view-from a metaphysical viewpoint he had very little to say about moral philosophy: ${ }^{3}$

I should like to exclude all value judgments from philosophy, except that this would be too violent a breach with usage. The only matter concerned with ethics that I can regard as properly belonging to philosophy is the argument that ethical propositions should be expressed in the optative mood, not in the indicative (Russell, 1944, p. 47).

Of course, in the 1960s when Russell argued in favour of Britain's unilateral nuclear disarmament (and for the establishment of world government), Russell was not alone in taking little or no philosophical interest in the messy world of urgent moral problems. Among philosophers, at that time, his was a fairly typical attitude. This led to the situation, in the late '60s, of philosophy students-inspired in part by Russell's journalism (Pigden, 2003, pp. 478)—rebelling against the sterility of their moral philosophy courses when by contrast, outside of the lecture halls, there seemed to be much more interesting and urgent debates going on. ${ }^{4}$

The compartmentalisation of Russell's work can be illustrated by a comparison of the following two passages. In The History of Western Philosophy (1946), in criticism of what he saw as an unjustified assumption in the philosophy of Leibniz, Russell notes that: "There is a general belief (which I have never understood) that it is better to exist than not to exist; on this ground children are exhorted to be grateful to their parents" (Russell, 1946, p. 575). Compare this to the concluding words of Russell's radio broadcast of 23 December 1954 'Man's Peril' (made in the wake of the first H-bomb test):

\footnotetext{
3 Before his repudiation of idealism, his ambition had been "to synthesise, in classic Hegelian fashion, the demands of theory and practice" (Monk, 1996, p. 102) "His writings reveal the anguish of a philosopher with a yearning for moral truth who cannot reconcile the objectivity of ethics with his philosophical conscience" (Pigden, 1999, p. 6).

4 "In the United States there was a "disconnect" between what was going on in the university and what was happening in the streets. This was symbolised by the disruption of John Searle's ethics classes at Berkeley. Searle wanted to lecture on deriving an "ought" from an "is", while the students wanted to discuss the war in Vietnam." (Jamieson, 1999, p. 3)
} 
There lies before us, if we choose, continual progress in happiness, knowledge, and wisdom. Shall we, instead, choose death, because we cannot forget our quarrels? I appeal, as a human being to human beings: remember your humanity, and forget the rest. If you can do so, the way lies open to a new Paradise; if you cannot, nothing lies before you, but universal death (in Monk, 2000, p. 372).

There is an interesting contrast here, but not a contradiction, for these statements are made from non-competing viewpoints. The sentence taken from The History of Western Philosophy looks back towards non-existence. In 'Man's Peril' Russell looks ahead to the prospect of annihilation. Moreover, 'Man's Peril' does not necessarily contradict moral relativism. Reaching to the widest possible audience and appealing to your humanityRussell might still maintain that he is ultimately advocating 'only' the preservation of 'our' world.

The question then arises: in writing on moral and political problems, if Russell did not think of himself as writing as a philosopher, how did he think of himself? As already mentioned, he thought of himself as a journalist but, more specifically, and on the evidence of numerous approving references, it would seem that he thought of himself as, like Thomas Paine, speaking up on behalf of "common sense"-or, on one occasion, "educated common sense" (Russell, 1969, p. 162).

Paine's common sense:

is ultimately rooted neither in mass behaviour nor in common usage nor in universal consent. For all his false modesty in promising "nothing more" than simple facts and for all his devotion to the pronoun "we," Paine positions himself as a prophetic individual at that. Paine sees clearly what others cannot yet see (Rosenfeld, 2011, p. 149).

The same was true of Russell. He used 'common sense' in the same contradictory manner, customary since the Enlightenment. Like Paine, he spoke against common sense at the same time as insisting that he spoke for it. For what Russell told his readers was common sense was not actually common sense until they read him and were convinced by his arguments (and rhetoric).

The claim that Russell saw himself as a spokesman of common sense may engender some surprise, especially when we recall one of the most famous of all Russell quotes: "common sense is the metaphysics of savages." However, this quotation is almost certainly misattributed. The saying first occurs in scare quotes in a review of Russell's Our Knowledge of the External World (1914) by Douglas Clyde MacIntosh (MacIntosh, 1915, p. 243). Readers of the review might forgivably assume that MacIntosh is quoting Russell but actually the phrase is the reviewer's (see Leach, 2019).

Russell's attitude towards common sense was always, I believe, more charitable than the misattributed quotation has led us to believe. The following conversation was recalled by Gilbert Ryle:

A good many years ago I happened to be sitting with Earl Russell in the restaurant-car of a train to North Wales. Somehow our conversation turned to John Locke and I put to Russell this very question, perhaps with some hyperbole: "Why is it that, although nearly every youthful 
student of philosophy both can and does in his second essay refute Locke's entire Theory of Knowledge, yet Locke made a bigger difference to the whole intellectual climate of mankind than anyone had done since Aristotle?" Russell agreed that the facts were so, and suggested, on the spur of the moment, an answer which dissatisfied me. He said, "Locke was the spokesman of Common Sense." Almost without thinking I retorted impatiently, "I think Locke invented Common Sense." To which Russell rejoined "By God, Ryle, I believe you are right. No one ever had Common Sense before John Locke-and no one but Englishmen have ever had it since (Ryle, 1967, pp. 3-4).

But what exactly do we mean by common sense? Its proponents would have it that it is something more fundamental than the conventional wisdom prevalent at a particular time and place. They imply, without argument, that it is something like folk wisdom.

I am sceptical. It seems more likely that proclamations that cite common sense are thought to be true because (1) they are known with confidence; and (2) it is believed that all other right-thinking people also know them with confidence. (1) and (2) seem to have equal importance, which is not surprising as, socially, they reinforce each other. If I ask why I believe something that is common sense with confidence, the answer is that all others whom I think of as right-thinking people also seem to know it with confidence. And why do I think of them as right-thinking people? Well, they seem to be confident of the same things as me. The justification of common sense is circular. Yet there is an expectation of universality in that we are continually surprised that not everyone possesses it!

On occasion Russell refers to common sense in such a way as to mean no more than conventional 'wisdom'. For example in the final chapter of The Problems of Philosophy, 'The Value of Philosophy', he concludes:

The man who has no tincture of philosophy goes through life imprisoned in the prejudices derived from common sense, from the habitual beliefs of his age or his nation, and from convictions which have grown up in his mind without the cooperation or consent of his deliberate reason (Russell, 1912, p. 91).

But, away from philosophy, in his journalism Russell's attitude towards common sense is considerably less critical- "I am prepared to admit the ordinary beliefs of common sense, in practice if not in theory," (Russell, 1928, p. 12)-and his conception of common sense is closer to universally known good sense. Writing for the widest possible readership, it is apparent that his ambition, as a journalist, was not to test common sense but to speak on its behalf. He is, for example happy to describe The Conquest of Happiness (1930) as "a book of common sense advice" (Russell, 1968, p. 391). And, most obviously, in Common Sense and Nuclear Warfare (1959) Russell positions himself unequivocally, and without hesitation, on the side of common sense.

This was, I believe, a mistake, reflected in the worst qualities of his journalism. According to Wittgenstein, "Russell's books should be bound in two colours . . those dealing with mathematical logic in red-and all students of philosophy should read them; those dealing with ethics and politics in blue-and no one should be allowed to read them" (in Monk, 2000, p. 278). In his biography of Russell, Ray Monk describes Russell's work in the fields of practical ethics and politics, as (with a few exceptions): 
- glib

- over-polemical

- over-confident

- utopian

- wilfully shallow (playing to the gallery)

- concentrating on offering instant solutions

- ignoring questions of policy

- with a tendency to malign those of different opinions.

But then, in practical ethics and politics, Russell was aspiring to speak on behalf of common sense-and these characteristics are all typical of arguments that wave "the magic wand of common sense" (Kant, 1783, p. 369).

My point is not that because this is Monk's verdict we must accept it but that to extent that Monk is right it is owing to Russell's clearly stated ambition to speak for common sense.

\section{Can philosophy do better?}

An obvious feature of philosophy is its questioning of accepted conventions. In this respect it is the antithesis of common sense (in the sense of conventional wisdom). It is the questioning of convention that-so far-has kept us from the potentially disastrous consequences of military brinkmanship.

On 27 October 1962, during the Cuban missile crisis, vessels from the American navy surrounded the Soviet submarine B-59. They dropped depth charges to bring it to the surface. What the Americans did not know was that the exhausted Russian crew had had no contact with Moscow for many days and did not know whether or not war had already broken out. The Americans also did not know that the submarine carried a nuclear missile which the crew were authorised to launch without clearance from Moscow. The decision to launch the missile had only to be cleared by the three senior officers on board. Two were in favour, one of whom argued: "We will die, but we will sink them all - we will not disgrace our navy!" But the third officer, Vasili Arkhipov, disagreed (Tegmark, 2017, p. 112). He went against the common sense of his fellow officers and the momentum of cold war reasoning that, otherwise unchecked, was leading to catastrophe.

On 27 September 1983 Stanislav Petrov was on duty in a bunker near Moscow monitoring early warning satellites. He was covering for a sick colleague. Suddenly all of the alarms started ringing. Five incoming intercontinental missiles had been detected. Protocol demanded that he immediately inform his superiors. However, the fact that only five missiles seemed to have been launched and that ground-based radar installations had no evidence of an attack seemed a little odd. "I was 50-50 as to whether it was a real or a false alarm. In this situation I decided that maybe it's my mistake, but I don't want to start World War Three" (Anon., 2017). It eventually became apparent that the detection system had misread the sunlight glancing off the top of the late evening clouds.

Both Arkhipov nor Petrov disregarded the opinion of their peers. I do not know whether they had an interest in philosophy but they both fulfilled a necessary condition for its pursuit. They also both clearly believed that humanity is worth saving - a belief that is not necessarily a constituent of historically contingent common sense. 
But can philosophy itself intervene in the issue over which Russell was most concerned? I believe it can - and it can do so by challenging and attempting to change common sense. If one is making the point that because nuclear weapons have coincided with a period of peace for $\mathrm{x}$ many years that does not entail that they will coincide with a period of peace lasting $\mathrm{x}+$ 1 years, then one is ultimately making a philosophical argument, based on Hume's work on inductive reasoning. "That the sun will not rise tomorrow is no less intelligible a proposition, and implies no more a contradiction than that it will rise" (Hume, 1748, §4.8). On the evidence of recent debates on nuclear disarmament, this is an argument that has yet to be acknowledged by common sense.

On the weighing up of one specific policy against another, the philosopher qua philosopher may have less to say; but that is also an area in which common sense tends to have little to say. Nonetheless philosophy can clarify the choices before us, by revealing the presuppositions of opposing viewpoints. By contrast, common sense, invariably of conflicting varieties, obscures those choices, often by disparaging scientific opinion.

To be fair to Russell, it should be said that disparaging scientific opinion is not something that he went in for, but it is another fairly common trait of arguments that employ the magic wand of common sense.

And yet it is believed that philosophy "leaves everything as it is"- and that "poetry makes nothing happen" (Auden, 1940)—both are seen as precious but practically useless. But it would be more accurate to say that common sense leaves everything as it is.

That claim may seem doubtful to fly in the face of common sense, no less. After all, is it not the case that when socialism became common sense for many people at the beginning of the twentieth century that that changed history? In reply to this criticism, I do not deny that common sense can be changed. I would not deny, for example, that Thomas Paine's pamphlet on Common Sense helped bring about American independence. (Indeed, common sense must be made to change.) In large part, social history consists in tracing and explaining changes made to common sense. However, common sense itself does not change anything. It is inherently conservative.

Of course, in certain circumstances, its conservative power can be of great benefit. If I see a small child wandering too close to a fire or to the edge of a cliff it is common sense that I should call them back, and maintain the peaceful status quo. Here, it is a good thing that I do not have to debate what to do-that I can rely on common sense. Common sense here is, "as invaluable as the virtue of conformity in the army and navy" (Thoreau, 1849, p. 387). However, unless we are completely content with our present course then we must turn to something other than common sense-and here, to sum up, I would speak for the value of uncommon sense or philosophy.

Bernard Williams once posed the question: "what is the point of doing philosophy if you're not extraordinarily good at it?" (in Nagel, 1995, p. 10) Following the publication of his last ambitious work in philosophy, Human Knowledge: Its Scope and Limits (1948)_ unenthusiastically received - this may have been a question that Russell pondered.

But he may have thought that circumstances were such that the question no longer mattered. In 'The Duty of a Philosopher in This Age', written in 1964, Russell wrote that the philosopher's duty was now to forget philosophy and to study "the probable effects of 
a nuclear war": "He must, then, devote himself, by whatever means are open to him, to persuading other people to agree with him as to these effects and to joining him in whatever protest shows the most chance of success" (Russell, 1964, p. 459). "If they do not fulfil this duty they are accomplices to mass murder" (Russell, 1964, p. 457). This advice was presumably intended to apply to both extraordinarily good philosophers and those less good. (Thus, in this late work, Russell was in agreement with Marx: "The philosophers have only interpreted the world, in various ways. The point, however, is to change it" (Marx, 1845, §11).)

The counter-argument is that a philosopher who forgets philosophy is likely to be less effective at instigating change than one who remembers it. The philosophy in question does not need to be cutting-edge. As we have seen, it may be something as relatively elementary as Hume on induction.

To give Russell his due, although he tended to overestimate his influence, his journalism was not ineffective. (In particular, his 1954 broadcast on 'Man's Peril' can be seen as the catalyst that led to the setting up of the Pugwash Conferences on Science and World Affairs which in turn helped bring about the partial Test Ban treaty of 1964. $)^{5}$ We must be glad that he spoke out. But then Russell could not altogether forget his philosophy. He was aiming for, and, at least sometimes, achieving, logically tight arguments expressed in the clearest possible prose-and, for the achievement of these aims, a training in philosophy is second to none (although of course that is not to say that philosophy itself is always easy to read).

In fact, Russell had already answered Williams' question in The Problems of Philosophy. I shall quote the relevant passage once more:

The man who has no tincture of philosophy goes through life imprisoned in the prejudices derived from common sense, from the habitual beliefs of his age or his nation, and from convictions which have grown up in his mind without the cooperation or consent of his deliberate reason (Russell, 1912, p. 91).

There was no need for Russell to put aside this lesson as he moved from metaphysics to the more urgent problems of politics and applied ethics. Although cries of 'common sense' are more often heard in politics and applied ethics, in making this move, philosophy should not be automatically displaced by common sense.

Indeed, whether one is extraordinarily good at it or not, a large part of the value of philosophy is to challenge, and attempt to change, common sense. The alternative is to accept unquestioningly our current course and the inexorable drift of technological 'progress.'

\section{References}

Anon. (2017, September, 21). 'Stanislav Petrov' (obituary), The Times.

Auden, W.H. (1940). In Memory of W.B. Yeats. In Another Time. London and New York: Random House.

Hume, D. (1748/2007). An enquiry concerning human understanding. (P. Millican, Ed.). Oxford: Oxford University Press.

Jamieson, D. (1999) (Ed.). Singer and his critics. Oxford: Oxford University Press.

5 Russell was the figure head of the movement but his role should not eclipse the work of others. Einstein and Joseph Rotblat, and others, were involved in setting up the movement. 
Kant, I. (1783/2001). Prolegomena to any future metaphysics. (P. Carus, Trans., J.W. Ellington, Rev.). Indianapolis: Hackett.

Leach, S. (2019). Bertrand Russell and common sense. Philosophy Now, 135, 32-33.

Lichtenberg, G.C. (1768-1771/2012). Notebook B. In S. Tester (Ed.), Philosophical Writings. New York: SUNY Press.

MacIntosh, D.C. (1915). The problem of knowledge. New York: Macmillan.

Marx, K. (1845/1976). Theses on Feuerbach. In Karl Marx and Frederick Engels, Collected Works, Volume 5, 1845-1847. London: Lawrence and Wishart.

Monk, R. (1996). Bertrand Russell: The Spirit of Solitude, 1872-1921. London: Jonathan Cape.

Monk, R. (2000). Bertrand Russell: The Ghost of Madness, 1921-1970. London: Jonathan Cape.

Nagel, T. (1995). Other minds: Critical essays, 1969-1994. Oxford: Oxford University Press.

Pigden, C. (1999). Preface and Introduction to Russell on Ethics. C. Pigden (Ed.). London: Routledge.

Pigden, C. (2003). Bertrand Russell: Moral philosopher or unphilosophical moralist? In The Cambridge Companion to Bertrand Russell (pp. 475-506). Cambridge: Cambridge University Press.

Rosenfeld, S. (2011). Common sense: A political history. Cambridge, MA: Harvard University Press.

Russell, B. (1912). The problems of philosophy. London: Oxford University Press.

Russell, B. (1914). Our knowledge of the external world. London: George Allen and Unwin.

Russell, B. (1923). The ABC of atoms. London: Kegan Paul.

Russell, B. (1924). Icarus or the future of science. London: Kegan Paul.

Russell, B. (1928). Sceptical essays. London: George Allen and Unwin.

Russell, B. (1931). The scientific outlook. London: George Allen and Unwin.

Russell, B. (1935). In praise of idleness. London: George Allen and Unwin.

Russell, B. (1944/1997). Replies to critics. In Last Philosophical Testament: 1943-68, J.G. Slater (Ed.). London: Routledge.

Russell, B. (1946). A history of western philosophy. London: George Allen and Unwin.

Russell, B. (1959). Common sense and nuclear warfare. London: George Allen and Unwin.

Russell, B. (1964/1997). The duty of a philosopher in this age. In The Collected Papers of Bertrand Russell: The Last Philosophical Testament, 1943-1968, Volume 11. J.G. Slater (Ed., with the assistance of P. Köllner). London and New York: Routledge.

Russell, B. (1968). The autobiography of Bertrand Russell 1914-1944 (Volume II). London: George Allen.

Ryle, G. (1967). John Locke. Critica: Revista Hispanoamericana de Filosofia, 1(2), 3-19.

Tegmark, M. (2017). Life 3.0: Being human in the age of artificial intelligence. London: Penguin (Allen Lane).

Thoreau, H.D. (1849/1980). A week on the Concord and Merrimack Rivers. Princeton: Princeton University Press.

Winner, L. (1986). The whale and the reactor: The search for limits in the age of technology. Chicago: University of Chicago Press.

Wittgenstein, L. (1953). Philosophical investigations ( $2^{\text {nd }}$ ed.). G.E.M. Anscombe \& R. Rhees (Eds.). Oxford: Blackwell.

School of Social, Political and Global Studies

Keele University, Keele

Staffordshire

ST5 5BG

United Kingdom

Email: s.d.leach@keele.ac.uk 